RAPID COMMUNICATION

\title{
Corticotropin-releasing hormone stimulates NF-кB in human epidermal keratinocytes
}

\author{
Blazej Zbytek ${ }^{1,2}$, Lawrence $\mathbf{M}$ Pfeffer $^{1}$ and Andrzej T Slominski ${ }^{1}$ \\ ${ }^{1}$ Department of Pathology and Laboratory Medicine, University of Tennessee Health Science Center, Memphis, TN, USA \\ ${ }^{2}$ Department of Histology and Immunology, Medical University of Gdansk, Gdansk, Poland \\ (Requests for offprints should be addressed to A Slominski; Email: aslominski@utmem.edu)
}

\begin{abstract}
Corticotropin-releasing hormone (CRH) has been shown to inhibit proliferation and modulate expression of inflammation markers in the epidermal cells. In the present study we report that $\mathrm{CRH}$ also stimulates nuclear factor-kappa B (NF- $\kappa B)$ activity. Incubation with $\mathrm{CRH}$ of human keratinocytes derived from primary cultures resulted in increased binding of DNA by NF-KB. CRH induced translocation of NF- $\mathrm{KB}$ subunit p65 from the cytoplasm to the nucleus and induced expression of $\kappa \mathrm{B}$-driven chloramphenicol acetyltransferase (CAT)
\end{abstract}

reporter gene. NF- $\mathrm{\kappa B}$ translocation was accompanied

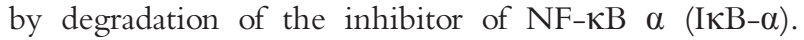
Specificity of the CRH effect was demonstrated by the use of CRH-R antagonists antalarmin and $\alpha$-helical CRH [9-41]. CRH-dependent stimulation of NF- $\mathrm{KB}$ activity is consistent with accumulated data about role of this neuropeptide in the regulation of local epidermal homeostasis.

Journal of Endocrinology (2004) 181, R1-R7

\section{Introduction}

Keratinocytes not only are the main building blocks of the epidermis, but also are regulators of the plentitude of local epidermal processes (reviewed in: Barker et al. 1991). Their role in immune reactions may involve constitutive expression of Toll-like receptors (Mempel et al. 2003), or regulated expression of cytokines and cytokine receptors, major histocompability complex II antigens and adhesion molecules (reviewed in: Barker et al. 1991, Freedberg et al. 2001). Keratinocytes express receptors to various neurotransmitters including catecholamines (reviewed in: Schallreuter 1997). Lastly, keratinocytes produce hormones and express corresponding receptors including effectors of the hypothalamo-pituitary-adrenal axis (reviewed in: Slominski et al. 2000c, 2001, Slominski \& Wortsman 2000).

Corticotropin-releasing hormone has a major role in coordinating the cellular stress response (Chrousos \& Gold 1992). CRH not only stimulates secretion of proopiomelanocortin (POMC)-derived peptides by corticotrophes, but also modulates the phenotype of many cell types. CRH actions in the immune system include induction of degranulation of mast cells, increased expression of interleukin (IL) 2 receptor and stimulation of lymphocyte proliferation (Singh 1989, Theoharides et al. 1998). CRHdependent production of IL-1 and IL-6 by leukocytes varies depending on activation status of these cells (Hagan et al. 1991, Leu \& Singh 1992, Pereda et al. 1995, Singh \& Leu 1990).

$\mathrm{CRH}$ is also produced locally in peripheral organs including the skin to regulate local homeostasis (Slominski et al. 1998, 2000b, 2000c 2001). Human keratinocytes express several isoforms of CRH receptor type 1 (CRHR1) (Pisarchik \& Slominski 2001, Slominski et al. 2001). $\mathrm{CRH}$ inhibits proliferation of both human primary and immortalized keratinocytes (Quevedo et al. 2001, Slominski et al. 2000a). CRH increases cyclic adenosine monophosphate (cAMP) production levels in immortalized keratinocytes (Slominski et al. 2000a) and calcium levels in both immortalized and human primary keratinocytes (Fazal et al. 1998, Slominski et al. 1999, Wiesner et al. 2002). CRH increases production of IL-6 and IL-11 in immortalized keratinocytes and increases both human leukocyte antigen DR (HLA-DR) and intercellular adhesion molecule 1 (ICAM-1) expression in human primary keratinocytes (Quevedo et al. 2001, Zbytek et al. 2002).

Inflammation and proliferation remain under the control of a plethora of transcription factors, with NF- $\mathrm{KB}$ 
considered to play an important role (reviewed in: Li \& Verma 2002). NF- $\kappa B$ activation is stimulated by many pathways that converge on I $\mathrm{KB}$ kinases including the signaling pathways activated by lipopolysaccharide, tumor necrosis factor $\alpha$ (TNF- $\alpha$ ) and T-cell receptor signaling. Phosphorylation and subsequent degradation of IкB proteins allow for release and then translocation of NF- $\mathrm{KB}$ to the nucleus, where it can bind to transcription-regulatory sequences to activate specific genes (Li \& Verma 2002). $\mathrm{CRH}$ was found to stimulate NF- $\mathrm{KB}$ activity in mouse thymocytes (Zhao \& Karalis 2002). In corticotrophic AtT20 cells, CRH suppressed NF- $\kappa$ B activity induced by hydrogen peroxide treatment (Lezoualc'h et al. 2000). In immortalized $\mathrm{HaCaT}$ keratinocytes $\mathrm{CRH}$ attenuated $\mathrm{NF}-\kappa \mathrm{B}$ activity that had been increased by removal of growth factors (Zbytek et al. 2003).

To further characterize the physiological role of $\mathrm{CRH}$ in the epidermis we examined the effects of $\mathrm{CRH}$ on human adult primary keratinocytes.

\section{Materials and Methods}

\section{Cell culture}

Human epidermal keratinocytes derived from adult skin were cultured in Epilife medium (containing bovine serum albumin (BSA), bovine transferrin, hydrocortisone, recombinant human insulin-like growth factor type-1, prostaglandin $\mathrm{E}_{2}$, recombinant human epidermal growth factor, penicillin $\mathrm{G}(100 \mathrm{U} / \mathrm{ml})$, streptomycin $(100 \mu \mathrm{g} / \mathrm{ml})$, amphotericin B $(0 \cdot 25 \mu \mathrm{g} / \mathrm{ml})$ and calcium at 0.06 mM, Cascade Biologics, Inc., Portland, OR).

Cells from the third or fourth passage were seeded at density 10,000 cells $/ \mathrm{cm}^{2}$ and grown for $48 \mathrm{~h}$ before addition of CRH to final concentration of 1 or $100 \mathrm{nM}$ (Molecular Research Lab, NC), phorbol 12-myristate 13-acetate (PMA, $100 \mathrm{nM}$, Sigma, St Louis, MO) or interferon $\gamma(1000 \mathrm{U} / \mathrm{ml}$, Biosource, Camarillo, CA).

\section{Electrophoretic mobility shift assay}

Nuclei extracts were prepared as previously described (Yang et al. 2000) and were used for electrophoretic mobility shift assay (EMSAs). A NF- $\kappa B$ oligonucleotide probe (Promega, Madison, WI) was end-labeled with $\left[\gamma-{ }^{32} \mathrm{P}\right]$ deoxy-ATP using T4 polynucleotide kinase. Binding reaction constisted of $5 \mu \mathrm{g}$ of nuclear extract, $\sim 0.05 \mathrm{pM}$ of NF- $\kappa \mathrm{B}$ oligonucleotide probe, $1 \mu \mathrm{g}$ of double strand poly $(\mathrm{dI}) \bullet \operatorname{poly}(\mathrm{dC}), 5 \mu \mathrm{l}$ of $5 \mathrm{X}$ incubation buffer $(10 \mathrm{mM}$ Tris-HCl, $\mathrm{pH}=7 \cdot 5,1 \mathrm{mM}$ EDTA, $\mathrm{pH}=8,40 \mathrm{mM} \mathrm{NaCl}, 4 \%$ v/v glycerol, $0.008 \% \mathrm{v} / \mathrm{v}$ $\beta$-mercaptoethanol) and water in a final volume of $25 \mu \mathrm{l}$. The protein-DNA complexes were separated on 5\% polyacrylamide gel. For supershift assays nuclear extracts were incubated with antibodies $(0 \cdot 2 \mu \mathrm{g}$ per assay) to either p50 (sc-1190), p65 (sc-109), c-rel (sc-70) or p52 (sc-298)
(Santa Cruz Biotechnology Inc., Santa Cruz, CA). To determine binding specificity, a 50x excess of unlabelled oligonucleotide was used. Radioactivity was quantitated with Packard Cyclone phosphorimager, and analyzed with Optiquant (Perkin-Elmer Life Sciences Inc., Boston, MA) and Adobe Photoshop (San Jose, CA) software.

\section{Reporter gene assay}

Keratinocytes were transfected using Lipofectamine Plus reagent (Gibco, Invitrogen Life Technologies, Carlsbad, $\mathrm{CA})$ with either the pUX-CAT promoterless chloramphenicol acetyltransferase construct or pUX-CAT 3 $\mathrm{XHLA \kappa B}$ construct, which contains three tandemly repeated copies of NF- $\mathrm{KB}$ site from HLA-B7 gene (provided by Dr. J. Vilcek, New York University Medical Center). To demonstrate the specificity of CRH action, $1 \mathrm{~h}$ before addition of $\mathrm{CRH}$, either CRH-R non-peptide antagonist antalarmin $(10 \mu \mathrm{M}$, Sigma, St Louis, MO) or peptide antagonist $\alpha$-helical CRH [9-41] (10 $\mu$ M, Sigma, St Louis, MO) was added. CAT activity was assayed by thin layer chromatography and quantitated by phosphorimaging using Optiquant software (Packard Cyclone, Perkin-Elmer Life Sciences Inc., Boston, MA) and normalized to expression of $\mathrm{pSV}-\beta$-galactosidase control vector (Promega, Madison, WI).

\section{Immunolocalization of p65 in epidermal cells (confocal laser microscopy)}

Cells were seeded in 8 well Lab-Tek II chamber slides (Nalge Nunc, Inc., Naperville, IL). Subconfluent cells were stimulated with $100 \mathrm{nM}$ CRH for $60 \mathrm{~min}$ and fixed with $4 \%$ paraformaldehyde (in phosphate buffered saline (PBS)) for $10 \mathrm{~min}$. The cells were permeabilized with $0 \cdot 1 \%$ Triton X-100 (in PBS) for 5 min and blocked with $1 \%$ BSA (in PBS) for $30 \mathrm{~min}$. Then cells were stained consecutively with rabbit primary anti-human p65 antibody (sc-372) for $1 \mathrm{~h}$ (Santa Cruz Biotechnology, Inc., Santa Cruz, CA), anti-rabbit streptavidin conjugate for $1 \mathrm{~h}$ and FITC-avidin conjugate (Vector Laboratories, Inc., Burlingame, CA) for $30 \mathrm{~min}$ in buffer containing $0 \cdot 1 \%$ Triton X-100, 1\% BSA in PBS. The slides were extensively washed with PBS between stainings, and then mounted with Vectashield mounting medium (Vector Laboratories, Inc., Burlingame, CA). Slides not stained with primary antibody were used as background controls. Slides were observed with laser scanning confocal fluorescent microscope (LSM 510, Carl Zeiss GmbH, Jena, Germany). Plan-Neofluor oil immersion 40x objective, excitation wavelength $488 \mathrm{~nm}$ and long pass filter $560 \mathrm{~nm}$ were used and $0.47 \mu \mathrm{m}$ optical sections were generated.

\section{Western blot analysis of I $\mathrm{B} B-\alpha$}

Cells were lysed in RIPA buffer and clarified by centrifugation $(10,000 \boldsymbol{g}, 10 \mathrm{~min})$. Cell lysates $(10 \mu \mathrm{g})$ were 


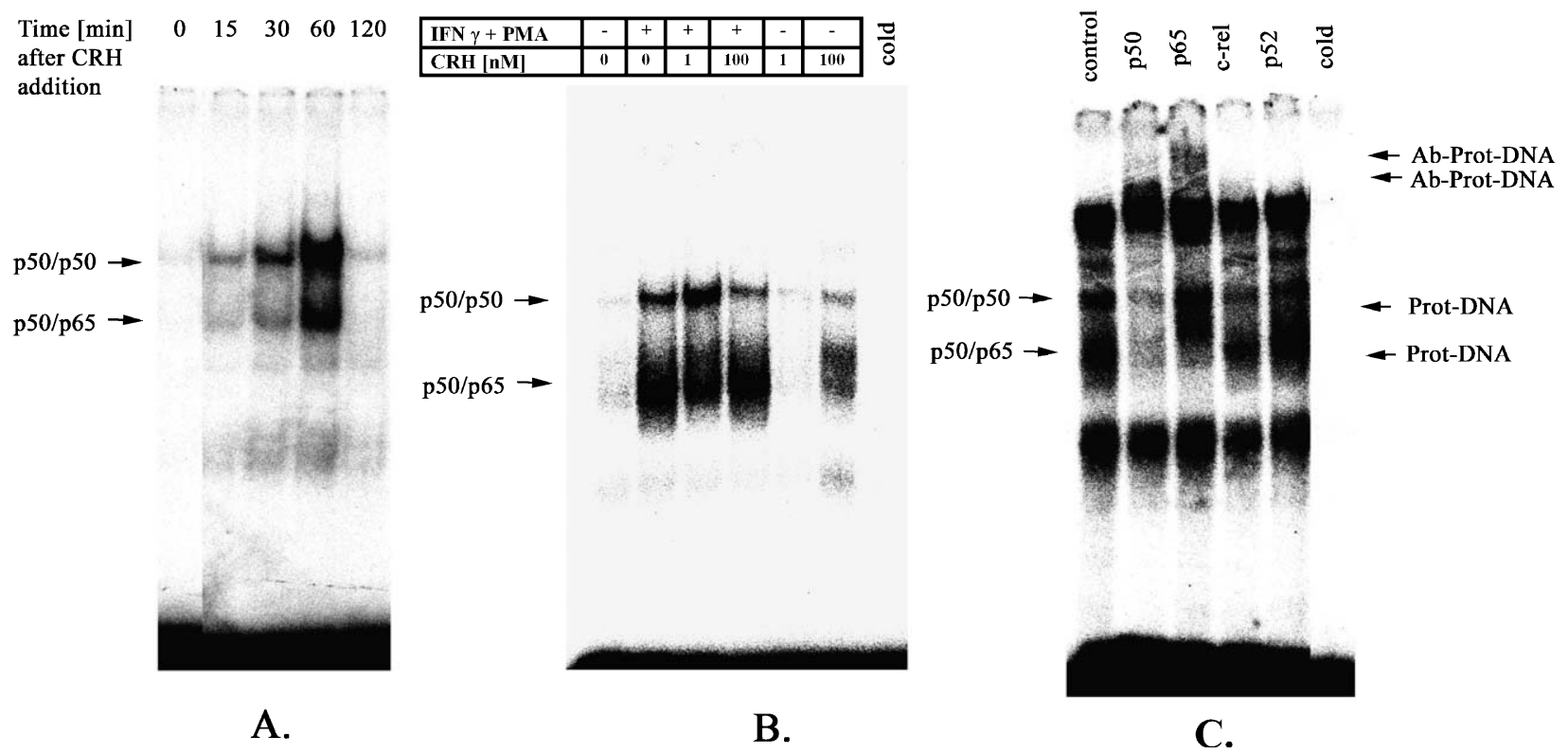

Figure $1 \mathrm{CRH}$ treatment increases NF-KB DNA binding activity in the keratinocytes. Nuclear extracts were prepared from cells grown in EpiLife medium and stimulated with CRH for indicated time periods. Nuclear extracts were subjected to EMSA. (A) $100 \mathrm{nM}$ CRH increased NF-KB DNA binding activity at the time-dependent manner. The activity increased at 15 min to reach maximum at 60 min. (B) At 60 min incubation CRH did not modify the NF-אB binding activity induced by interferon $\gamma($ IFN $\gamma)$ and PMA. Stimulatory effect of CRH was evident at $100 \mathrm{nM}$ but not at $1 \mathrm{nM}$ concentration. (C) Nuclear extracts obtained after 60 min incubation with CRH (control) were subjected to supershift assays with a panel of antibodies directed against various components ( $p 52, c-r e l, p 65, p 50)$ of NF- $\mathrm{kB}$ dimers. Cold represents nuclear extract pre-incubated with 50x excess of unlabelled oligonucleotide. Arrows denote protein-DNA or antibody-protein-DNA complexes. Results are representative of two separate experiments.

separated on $12 \%$ SDS-PAGE gel and transferred to the PVDF membrane. After blocking with Tris buffered saline, 0.05\% Triton X-100 and 5\% milk, the membranes were

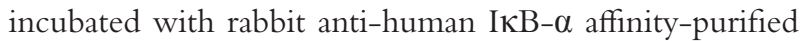
polyclonal IgG (sc-371, 1:200, Santa Cruz Biotechnology Inc., Santa Cruz, CA), followed by incubation with horseradish peroxidase conjugated goat anti-rabbit $\operatorname{IgG}$ (1:10000). IкB- $\alpha$ was visualized with Supersignal West Pico Chemiluminescent Substrate (Pierce, Rockford, IL). The membranes were stripped and reprobed with antibody against actin (1:500, Santa Cruz Biotechnology Inc., Santa Cruz, CA). The chemiluminescent signal was acquired on a Fluor-S Multilmager and analyzed with Quantity One software (Bio-Rad Laboratories, Hercules, CA).

\section{Statistical analysis}

Values are presented as means \pm S.E.M. Significance between test groups was determined by ANOVA and Tukey's multiple comparison post-hoc test using Prism 4.00 software (GraphPad Software, San Diego, CA).

\section{Results}

CRH stimulates NF- $\kappa B D N A$ binding activity in the keratinocytes

Human primary keratinocytes were grown in supplemented EpiLife medium and then stimulated with
$100 \mathrm{nM}$ CRH for 15, 30, 60 and $120 \mathrm{~min}$. After stimulation with $\mathrm{CRH}$, nuclear extracts were prepared and analyzed for NF- $\kappa B$ activation by EMSA (Fig. 1A). CRH induced NF- $\kappa B$ DNA binding activity at $15 \mathrm{~min}$ incubation and DNA binding further increased to reach maximum at $60 \mathrm{~min}$ incubation. NF- $\mathrm{KB}$ DNA binding activity returned to near the basal level at $120 \mathrm{~min}$ after $\mathrm{CRH}$ addition. The effect of CRH was dose dependent, i.e., was observed at $100 \mathrm{nM} \mathrm{CRH}$ and absent at $1 \mathrm{nM}$ CRH (Fig. 1B). As shown in Fig. 1, two CRH-induced $\mathrm{NF}-\kappa \mathrm{B}$ complexes were observed. In order to determine the composition of $\mathrm{CRH}$-induced NF- $\mathrm{KB}$ complexes, nuclear extracts were preincubated with antibodies to specific Rel proteins and analyzed by supershift assays (Fig. 1C). It was determined that, while the lower CRH-induced complex contains both p50 and a p65 protein, the upper complex only contains $\mathrm{p} 50$.

\section{$C R H$ induces $\kappa B$-driven reporter gene activity in the} keratinocytes

In order to determine whether increase in NF- $\mathrm{KB}$ DNA binding activity has functional consequences in the keratinocytes, we performed gene reporter assays with a CAT construct driven by the $\mathrm{\kappa B}$ site derived from HLA-B7 gene. As shown in Fig. 2, incubation of transiently transfected keratinocytes with $\mathrm{CRH}$ increased CAT 


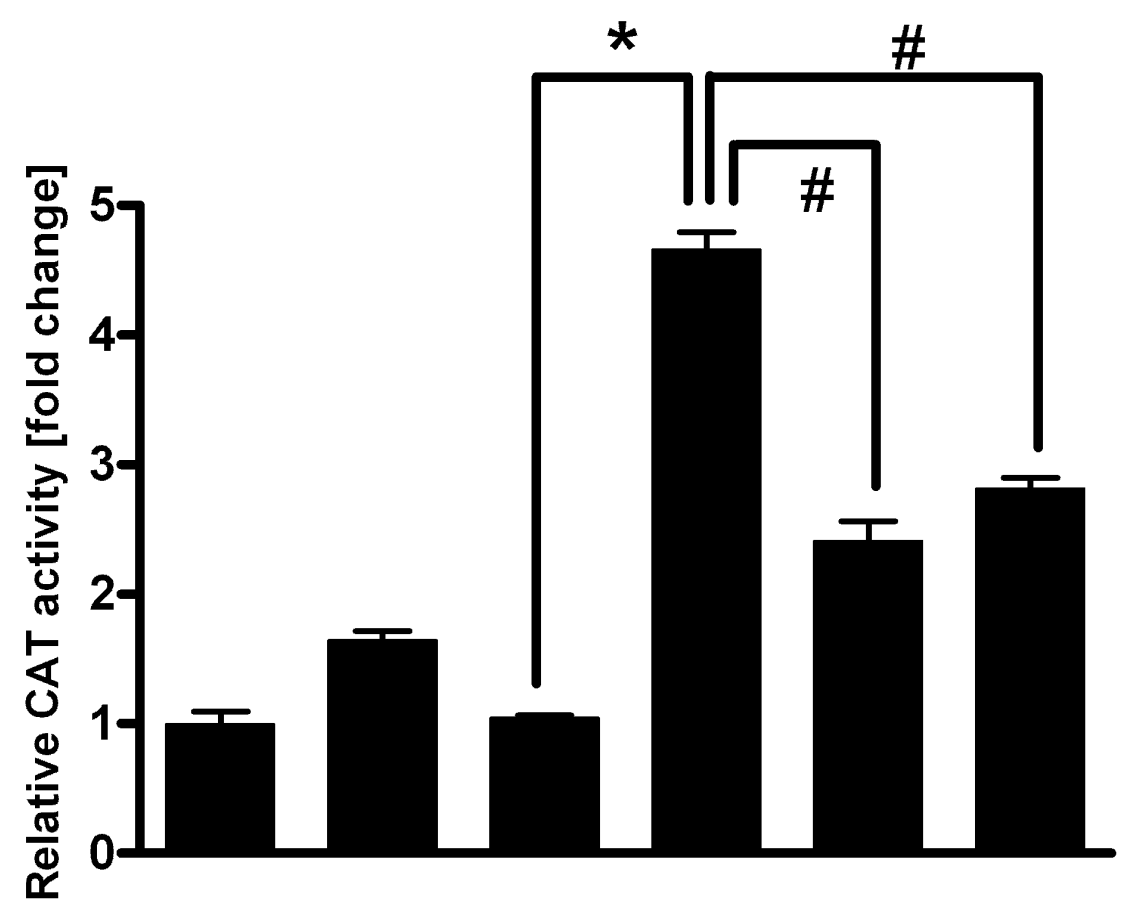

\begin{tabular}{|l|c|c|c|c|c|c|c|c|c|c|}
\hline promote rless construct & + & + & - & - & - & - \\
\hline NF-KB dependent construct & - & - & + & + & + & + \\
\hline CRH & - & + & - & + & + & + \\
\hline$\alpha-$ helical CRH [9-41] & - & - & - & - & + & - \\
\hline Antalarmin & & - & - & - & - & + \\
\hline
\end{tabular}

Figure $2 \mathrm{CRH}$ increases NF-kB-dependent transcriptional activity in keratinocytes. Keratinocytes were transiently transfected with pUX-CAT (construct without $\kappa B$ site) or pUX-CAT 3 XHLAкB (construct containing $\kappa B$ site) vector, incubated for 60 min without (untreated) or with $100 \mathrm{nM} \mathrm{CRH}$, in the absence and presence of CRH-R antagonists (antalarmin and a-helical CRH [9-41]), and assayed for CAT activity. The data represents a representative of three experiments performed in triplicate and values are presented as means \pm S.E.M. after subtraction of background, related to activity of the construct without $\kappa B$ site $(=1)$. ${ }^{*} P<0 \cdot 001$ between control (no treatment) and $\mathrm{CRH}$ treatment. $\# P<0.001$ between $\mathrm{CRH}$ treatment and $\mathrm{CRH}$ treatment in the presence of antagonists.

activity by $4 \cdot 4$-fold. Preincubation of cells for $1 \mathrm{~h}$ with both non-peptide (antalarmin) and peptide ( $\alpha$-helical $\mathrm{CRH}$ [9-41]) $\mathrm{CRH}$ antagonists significantly attenuated the CRH-induced signal. In contrast, CRH had no significant effect on the promoterless construct, which demonstrated that observed effects are $\mathrm{\kappa B}$-dependent.

\section{CRH induces $p 65$ translocation in keratinocytes}

To further characterize the activation of NF- $\mathrm{KB}$ by $\mathrm{CRH}$, we examined the cellular localization of the $\mathrm{p} 65$ protein in the keratinocytes by confocal microscopy. The p65 protein was detected in CRH-induced complexes by gel shift assays,. In normal human keratinocytes, p65 is localized mainly in the cytoplasm with little nuclear staining detectable. Treatment with $100 \mathrm{nM}$ CRH for $60 \mathrm{~min}$ induced translocation of p65 antigen from the cytoplasm into the nucleus. At 120 min incubation p65 was localized predominantly in the cytoplasm (Fig. 3). The transient translocation of p65 into the nucleus closely parallels its appearance in nuclear extracts as determined in gel shift assays (Fig. 1).

\section{Western blot for $I \kappa B-\alpha$}

Inhibitory I $\kappa \mathrm{B}$ proteins sequester NF- $\kappa \mathrm{B}$ in the cytoplasm and tightly control the activity of NF- $\kappa B$. Phosphorylation, ubiquitination and degradation of I $\kappa \mathrm{B}$ proteins precedes NF- $\kappa B$ release and translocation to the nucleus (Li \& Verma 2002). To determine whether NF-кB 


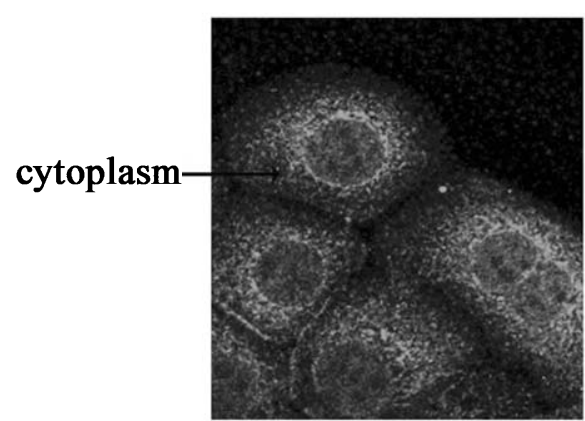

control

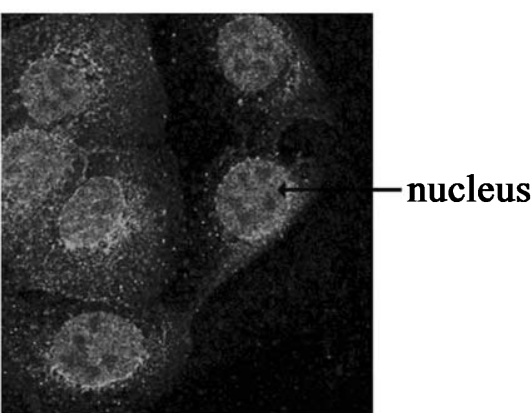

CRH 60 min.

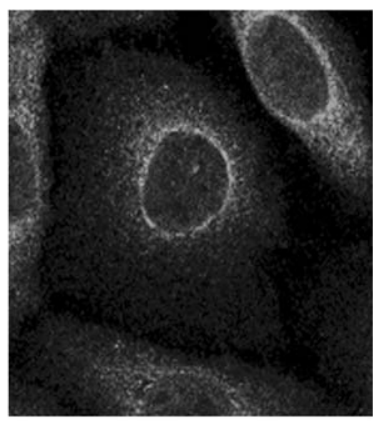

CRH 120 min.

Figure $3 \mathrm{CRH}$ induces p65 translocation from the cytoplasm to the nucleus. Keratinocytes were grown on 8 well chamber slides in growth media. $100 \mathrm{nM} \mathrm{CRH}$ was added for 60 and $120 \mathrm{~min}$, cells were then fixed and stained with p65 antibody. Control cells were not subjected to any treatment. The images were collected with fluorescent laser scanning confocal microscope. Results are representative of three separate experiments. Arrows denote the expression of p65 antigen in the cytoplasm or nucleus, respectively.

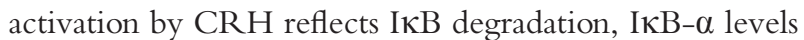
were determined after $\mathrm{CRH}$ addition by immunoblotting. As shown in Fig. 4, the CRH induced I $\mathrm{CB}-\alpha$ degradation in keratinocytes in a time-dependent manner. Level of I $\mathrm{BB}-\alpha$ decreased by $68 \%$ at $30 \mathrm{~min}$ and $50 \%$ at $60 \mathrm{~min}$ incubation. Thus, $\mathrm{CRH}$-induced degradation of IкB- $\alpha$ preceded the increase in NF- $\mathrm{\kappa B}$ DNA binding activity, which was maximal at $60 \mathrm{~min}$ (see Fig. 1 for comparison). As I $\kappa B-\alpha$ has a $\kappa B$ site in its promoter, activation of $\mathrm{NF}-\kappa \mathrm{B}$ results in up-regulation of I $\kappa \mathrm{B}-\alpha$ production ( $\mathrm{Li} \&$ Verma 2002). Indeed, at $120 \mathrm{~min}$ IкB- $\alpha$ returned to near basal levels, which reflects this latter process.

\section{Discussion}

We have recently documented (Zbytek et al. 2003) that $\mathrm{CRH}$ inhibits NF- $\kappa \mathrm{B}$ signaling in the immortalized line of $\mathrm{HaCaT}$ keratinocytes. In those cells, withdrawal of growth factors resulted in the enhancement of NF- $\mathrm{KB}$ signal and addition of $\mathrm{CRH}$ has markedly attenuated NF- $\mathrm{KB}$ activation. In the present study we have shown that $\mathrm{CRH}$

\section{Time [min] $\quad \begin{array}{llllll}0 & 15 & 30 & 60 & 120\end{array}$}

\section{IאB- $\alpha$}

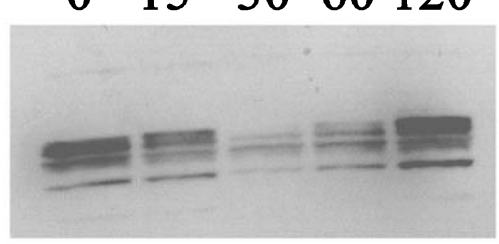

\section{actin}

Figure $4 \mathrm{CRH}$ induces I $\mathrm{\kappa} B-\alpha$ degradation. Keratinocytes were grown in growth media and $100 \mathrm{nM} \mathrm{CRH}$ was then added for indicated time periods. Total cell lysates were analyzed by immunoblotting. Results are representative of three separate experiments. stimulates NF- $\mathrm{KB}$ translocation from cytoplasm to nucleus followed by binding to specific DNA sequence and enhancement of $\mathrm{\kappa B}$-driven transcription activity in the human normal epidermal keratinocytes derived from primary cultures.

Factors such as TNF- $\alpha$, phorbol esters and interferon $\gamma$ increase NF- $\mathrm{KB}$ activity in human keratinocytes (Chaturvedi et al. 1999, Qin et al. 2001). Signaling pathways triggered by these substances differ but they converge at the activation of IKB kinases which subsequently phosphorylate I $\kappa \mathrm{B}$ proteins that are later ubiquitinated and degraded. This is followed by NF- $\mathrm{KB}$ release and translocation to nucleus. In contrast to $\mathrm{HaCaT}$ cells where NF- $\kappa \mathrm{B}$ activation by growth factor removal and attenuation of this process by CRH was linked to I $\mathrm{CB}-\beta$ degradation, in human primary keratinocytes $\mathrm{CRH}$ caused

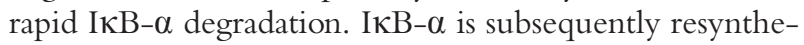
sized due to the presence of $\mathrm{NF}-\kappa \mathrm{B}$ response element in the I $\kappa \mathrm{B}-\alpha$ gene promoter ( $\mathrm{Li} \&$ Verma 2002). Bands detected by the IKB- $\alpha$ specific antibody represent both unphosphorylated and phosphorylated forms. IкB- $\alpha$ phosphorylation occurs at Ser 32 and 36 at the amino terminus (Li \& Verma 2002).

To further characterize CRH effects on NF- $\mathrm{KB}$ activity in the keratinocytes, we have subjected the cells to the combined treatment with phorbol ester and interferon $\gamma$, which are recognized stimulants of $\mathrm{NF}-\kappa \mathrm{B}$ activity (Chaturvedi et al. 1999, Quin et al. 2001). Although phorbol ester and interferon $\gamma$ treatment resulted in the increase of NF- $\kappa B$ activity, $\mathrm{CRH}$ did not alter this response (Fig. 1B). Lack of signal modification may suggest that either protein kinase $\mathrm{C}$ (PKC) pathway (stimulated by phorbol esters) or Janus kinase/signal transducer and activator of transcription (JAK/STAT) pathway (stimulated by interferons) may be involved in signaling between $\mathrm{CRH}$ receptor and IKB kinases. Indeed, $\mathrm{CRH}$ may stimulate PKC pathway (reviewed in: Slominski et al. 2000c) and the JAK/STAT signaling pathway is involved 
in enhancement of transcription of POMC gene, which is a major target gene of CRH signal (Ray et al. 1998).

We have found that CRH treatment results in translocation of the p65 protein, increases binding activity by p50/p50 and p65/p50 dimers, and increases transcriptional activity of $\kappa \mathrm{B}$-dependent reporter construct. NF- $\mathrm{\kappa B}$ dimers containing p65 are generally considered to stimulate gene expression (Li \& Verma 2002). This data is consistent with reported enhancement of HLA-DR and ICAM-1 expression in human primary keratinocytes and inhibition of proliferation of these cells (Quevedo et al. 2001). HLA-DR and ICAM-1 genes possess $\mathrm{KB}$ binding sites (Li \& Verma 2002). NF- $\mathrm{KB}$ activation in the keratinocytes results in growth arrest dependent on suppression of cyclin dependent kinase (cdk) 4 and upregulation of $\mathrm{cdk}$ inhibitor p21 (Dajee et al. 2003, Seitz et al. 2000).

$\mathrm{CRH}$-induced $\mathrm{NF}-\kappa \mathrm{B}$ activation in human primary keratinocytes is consistent with reported $\mathrm{CRH}$-induced $\mathrm{NF}-\mathrm{KB}$ activation in the immune system (Zhao \& Karalis 2002). Triggering the NF- $\kappa B$ pathway by $\mathrm{CRH}$ in keratinocytes is yet another argument supporting the existence of local epidermal regulatory circuits that are based on substances found in the nervous system (Slominski et al. 1998, 2000b, 2000c 2001). Because the skin has to react to noxious environmental stimuli it must be able to differentiate among them and respond accordingly in a localized and timely manner. Stressors such as ultraviolet light, bacteria or viruses are known to stimulate NF- $\mathrm{KB}$ activity. CRH may be one of the messengers that deliver information about noxious stimuli from cells that detect foreign antigens (e.g. Langerhans cells) to responders (e.g. lymphocytes or keratinocytes).

In summary, we have demonstrated for the first time that $\mathrm{CRH}$ can trigger the stress-related NF- $\mathrm{KB}$ pathway in human adult epidermal keratinocytes derived from primary cultures.

\section{Acknowledgements}

The work was supported by National Institutes of Health grants CA 73753 (L M P), AR047079 (A S) and Johnson and Johnson Skin Research Training Grant (B Z). Confocal microscopy was performed on the equipment obtained through Shared Instrumentation Grant from National Center for Research Purposes at the National Institutes of Health (S10 RR13725-01) with the excellent technical assistance of Ms. Carolyn Matthews.

\section{References}

Barker JN, Mitra RS, Griffiths CE, Dixit VM \& Nickoloff BJ 1991 Keratinocytes as initiators of inflammation. Lancet 337 211-214.

Chaturvedi V, Qin JZ, Denning MF, Choubey D, Diaz MO \& Nickoloff BJ 1999 Apoptosis in proliferating, senescent, and immortalized keratinocytes. Journal of Biological Chemistry 274 23358-23367.
Chrousos GP \& Gold PW 1992 The concepts of stress and stress system disorders. Journal of the American Medical Association 267 1244-1252.

Dajee M, Lazarov M, Zhang JY, Cai T, Green CL, Russell AJ, Marinkovich MP, Tao S, Lin Q, Kubo Y \& Khavari PA 2003 $\mathrm{NF}-\kappa \mathrm{B}$ blockade and oncogenic Ras trigger invasive human epidermal neoplasia. Nature 421 639-643.

Fazal N, Slominski A, Choudhry MA, Wei ET \& Sayeed MM 1998 Effect of CRF and related peptides on calcium signaling in human and rodent melanoma cells. FEBS Letters 435 187-190.

Freedberg IM, Tomic-Canic M, Komine M \& Blumenberg M 2001 Keratins and the keratinocyte activation cycle. Journal of Investigative Dermatology 116 633-640.

Hagan P, Poole S \& Bristow AF 1992 Immunosuppresive activity of corticotropin-releasing factor. Inhibition of interleukin-1 and interleukin-6 production by human mononuclear cells. Biochemical Journal 281 251-254.

Leu Sj \& Singh VK 1992 Stimulation of interleukin-6 production by corticotropin-releasing factor. Cellular Immunology 143 220-227.

Lezoualc'h F, Engert S, Berning B \& Behl C 2002 Corticotropinreleasing hormone-mediated neuroprotection against oxidative stress is associated with the increased release of non-amyloidogenic amyloid $\beta$ precursor protein and with the suppression of NF- $\kappa B$. Molecular Endocrinology 14 147-159.

Li Q \& Verma IM 2002 NF- $\mathrm{KB}$ regulation in the immune system. Nature Reviews. Immunology 2 725-734.

Mempel M, Voelcker V, Köllisch G, Plank C, Rad R, Gerhard Mi, Schnopp C, Fraunberger P, Walli AK, Ring J, Abeck D \& Ollert M 2003 Toll-like receptor expression in human keratinocytes: nuclear factor- $\mathrm{\kappa B}$ controlled gene activation by Staphylococcus aureus is toll-like receptor 2 but not toll-like receptor 4 or platelet activating factor receptor dependent. Journal of Investigative Dermatology 121 1389-1396.

Pereda MP, Saucer J, Castro CP, Finkielman S, Stalla GK, Holsboer F \& Arzt E 1995 Corticotropin-releasing hormone differentially modulates the interleukin-1 system according to the level of monocyte activation by endotoxin. Endocrinology 136 5504-5510.

Pisarchik A \& Slominski AT 2001 Alternative splicing of CRH-R1 receptors in human and mouse skin: identification of new variants and their differential expression. FASEB Journal 15 2754-2756.

Quevedo ME, Slominski A, Pinto W, Wei E \& Wortsman J 2001 Pleiotropic effects of corticotropin-releasing hormone on normal human skin keratinocytes. In Vitro Cellular and Developmental Biology. Animal 37 50-54.

Qin JZ, Bacon P, Chaturvedi V \& Nickoloff BJ 2001 Role of NF-кB activity in apoptotic response of keratinocytes mediated by interferon-gamma, tumor necrosis factor-alpha, and tumor-necrosis-factor-related apoptosis-inducing ligand. Journal of Investigative Dermatology 117 898-907.

Ray DW, Ren SG \& Melmed S 1998 Leukemia inhibitory factor regulates pro-opiomelanocortin transcription. Annals of the New York Academy of Sciences 840 162-173.

Schallreuter KU 1997 Epidermal adrenergic signal transduction as part of the neuronal network in the human epidermis. Journal of Investigative Dermatology Symposium Proceedings 2 37-40.

Singh VK 1989 Stimulatory effect of corticotropin-releasing neurohormone on human lymphocyte proliferation and interleukin-2 receptor expression. Journal of Neuroimmunology 23 257-262.

Seitz CS, Deng H, Hinata K, Lin Q \& Khavari PA 2000 Nuclear factor- $\mathrm{\kappa B}$ subunits induce epithelial cell growth arrest. Cancer Research 60 4085-4092.

Singh VK \& Leu SC 1990 Enhancing effect of corticotropin-releasing neurohormone on the production of interleukin-1 and interleukin-2. Neuroscience Letters 120 151-154.

Slominski AT, Botchkarev V, Choudhry M, Fazal N, Fechner K, Furkert J, Krause E, Roloff B, Sayeed M, Wei E et al. 1999 
Cutaneous expression of $\mathrm{CRH}$ and CRH-R. Is there a 'skin stress response system?' Annals of the New York Academy of Sciences $\mathbf{8 8 5}$ 287-311.

Slominski A, Ermak G, Mazurkiewicz JE, Baker J \& Wortsman J 1998 Characterization of corticotropin-releasing hormone (CRH) in human skin. Journal of Clinical Endocrinology and Metabolism $\mathbf{8 3}$ 1020-1024.

Slominski AT, Roloff B, Zbytek B, Wei ET, Fechner K, Curry J \& Wortsman J 2000a Corticotropin-releasing hormone and related peptides can act as bioregulatory factors in human keratinocytes. In Vitro Cellular and Developmental Biology. Animal 36 211-216.

Slominski A, Szczesniewski A \& Wortsman J 2000b Liquid chromatography-mass spectrometry detection of corticotropin-releasing hormone and proopiomelanocortin-derived peptides in human skin. Journal of Clinical Endocrinology and Metabolism 85 3582-3588.

Slominski A \& Wortsman J 2000 Neuroendocrinology of the skin. Endocrine Reviews 21 457-487.

Slominski A, Wortsman J, Luger T, Paus R \& Salomon S 2000c Corticotropin-releasing hormone and proopiomelanocortin involvement in the cutaneous response to stress. Physiological Reviews 80 979-1020.

Slominski AT, Wortsman J, Pisarchik A, Zbytek B, Linton EA, Mazurkiewicz JE \& Wei ET 2001 Cutaneous expression of corticotropin releasing hormone $(\mathrm{CRH})$, urocortin, and $\mathrm{CRH}$ receptors. FASEB Journal 15 1678-1693.

Theoharides TC, Singh LK, Boucher W, Pang X, Letourneau R, Webster E \& Chrousos G 1998 Corticotropin releasing hormone induces skin mast cell degranulation and increased vascular permeability, a possible explanation for its pro-inflammatory effects. Endocrinology 139 403-413.

Wiesner B, Roloff B, Fechner K \& Slominski A 2003 Intracellular calcium measurements of single human skin cells after stimulation with corticotropin releasing factor and urocortin using confocal laser scanning microscopy. Journal of Cell Science 116 1261-1268.

Yang CH, Murti A, Pfeffer SR, Basu L, Kim JG \& Pfeffer LM 2000 IFN $\alpha / \beta$ promotes cell survival by activating NF- $\kappa \mathrm{B}$. PNAS 97 13631-13636.

Zbytek B, Mysliwski A, Slominski A, Wortsman J, Wei ET \& Mysliwska J 2002 Corticotropin releasing hormone affects cytokine production in human $\mathrm{HaCaT}$ keratinocytes. Life Sciences $\mathbf{7 0}$ 1013-1021.

Zbytek B, Pfeffer LM \& Slominski AT 2003 Corticotropin releasing hormone inhibits nuclear factor- $\kappa \mathrm{B}$ pathway in human $\mathrm{HaCaT}$ keratinocytes. Journal of Investigative Dermatology 121 1496-1499.

Zhao J \& Karalis K 2002 Regulation of nuclear factor- $\kappa B$ by corticotropin releasing hormone in mouse thymocytes. Molecular Endocrinology 16 2561-2570. 